\title{
Aluminium in compacted graphite iron
}

\author{
*Grzegorz Gumienny', Barbara Kurowska', Leszek Klimek ${ }^{2}$ \\ 1. Lodz University of Technology, Department of Materials Engineering and Production Systems, Stefanowskiego 1/15, 90-924 Łódź, Poland \\ 2. Lodz University of Technology, Department of Materials Engineering, Stefanowskiego 1/15, 90-924 Łódź, Poland
}

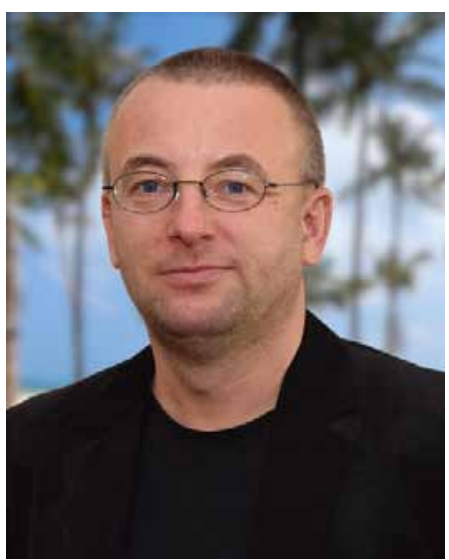

*Grzegorz Gumienny

Male, born in 1974, Ph. D., Professor, a member of Technical Association of Polish Foundrymen, and Foundry Commission of Polish Academy of Sciences. He got his Ph. D in technical sciences, Lodz University of Technology in 2003.

Research interests and achievements: foundry engineering, casting materials, abrasion resistant materials. To date, he has published 75 technical papers in peer-reviewed journals, and a monograph entitled "The selected aspects of the theory and technology of ductile cast iron with carbides obtained in the raw state".

E-mail: grzegorz.gumienny@p.lodz.pl

Received: 2019-07-24

Accepted: 2019-12-15

\begin{abstract}
Compacted graphite was obtained using inmold technology. The effect of aluminium on the crystallization process, microstructure, ferrite microhardness, and hardness of compacted graphite iron was studied. The microscopic and diffraction tests were also performed, and the process of cast iron crystallization was also investigated. Results show that aluminium increases the temperature of the eutectic transformation as well as the transformation temperature in the solid state. It is found that aluminium is a graphite forming element in compacted graphite iron (CGI) at a concentration up to $2.4 \mathrm{wt} . \%$. When its concentration is higher than $3.1 \mathrm{wt} . \%$, aluminium causes the spheroidization of the carbides in eutectoid mixture. It is also demonstrated that in cast iron with an aluminium content higher than $\sim 8 \mathrm{wt} . \%, \mathrm{AlFe}_{3} \mathrm{C}_{0.5}$ phase crystallizes from the liquid.
\end{abstract}

Key words: compacted graphite iron; aluminium; cooling curves

CLC numbers: TG143.49 Document code: A Article ID: 1672-6421(2020)02-137-07

A graphite formed in compacted graphite iron (CGI) is intermediate between the flake and spheroidal graphite. Compacted graphite is defined in EN ISO 945-1 as Type III. The mechanical properties of CGI are intermediate between gray and nodular cast iron. Its minimum tensile strength is from 300 to $500 \mathrm{MPa}$, with an elongation from $2 \%$ to $0.5 \%$. The interesting properties of CGI are the reason for the growing interest in this material ${ }^{[1-10]}$. Currently, it is used for the casing of diesel engines and turbine housings. Some alloying elements are added to increase the mechanical properties (e.g. by adding a pearlite-forming element) or to increase heat resistance. Aluminium is one of the elements that increase the heat resistance in iron alloys. It is a strong ferrite forming element in the cast iron. According to the results in Ref. [11], the $\gamma^{\prime}$ phase (also referred to as $\kappa$ or $\mathrm{Fe}_{3} \mathrm{AlC}_{\mathrm{n}}$ ) appears in cast iron containing above 3.8wt.\% Al. Data concerning both Fe-Al-C ternary phase equilibrium diagrams as well as experimental results are presented in Refs. [11-17]. Figure 1 shows the isothermal sections of the Al-C-Fe system at 1,073 and 1,473 $\mathrm{K}^{[14]}$.

The figure shows that $\kappa$ phase appears in the Al-C-Fe alloys at $1,473 \mathrm{~K}$. Its chemical composition is variable as a function of temperature. This phase is found in cast iron containing up to $\sim 23 \mathrm{wt} . \% \mathrm{Al}$. At a higher concentration of aluminium, the $\mathrm{Al}_{4} \mathrm{C}_{3}$ phase appears.

In practice, aluminium is often added into the cast iron as an inoculant. Aluminium significantly affects the form of carbon in cast iron. Depending on its concentration, carbon can exist as graphite precipitates or in the form of carbides ${ }^{[18]}$. The increase in $\mathrm{Al}$ concentration up to $\sim 4 \mathrm{wt} . \%$ results in almost full graphitization of the cast iron. An increase in $\mathrm{Al}$ concentration to $\sim 8 \mathrm{wt} . \%$ results in the carbide precipitations. The strong graphitizing effect occurs also for $\sim 22 \mathrm{wt} . \% \mathrm{Al}^{[10]}$. Aluminium also increases the resistance of the cast iron to high temperature and corrosion. However, most of the researchers focus on the impact of aluminium on the crystallization process (especially eutectic and eutectoid transformation temperatures), microstructure, or properties of cast iron with compacted graphite ${ }^{[19-28]}$. Information can hardly be found in literature on the effect of Al on CGI obtained using inmold technology. Accordingly, the aim of this study is to investigate the effect of $\mathrm{Al}$ on the crystallization process, microstructure, as well as ferrite microhardness, and hardness of cast iron with compacted graphite. 

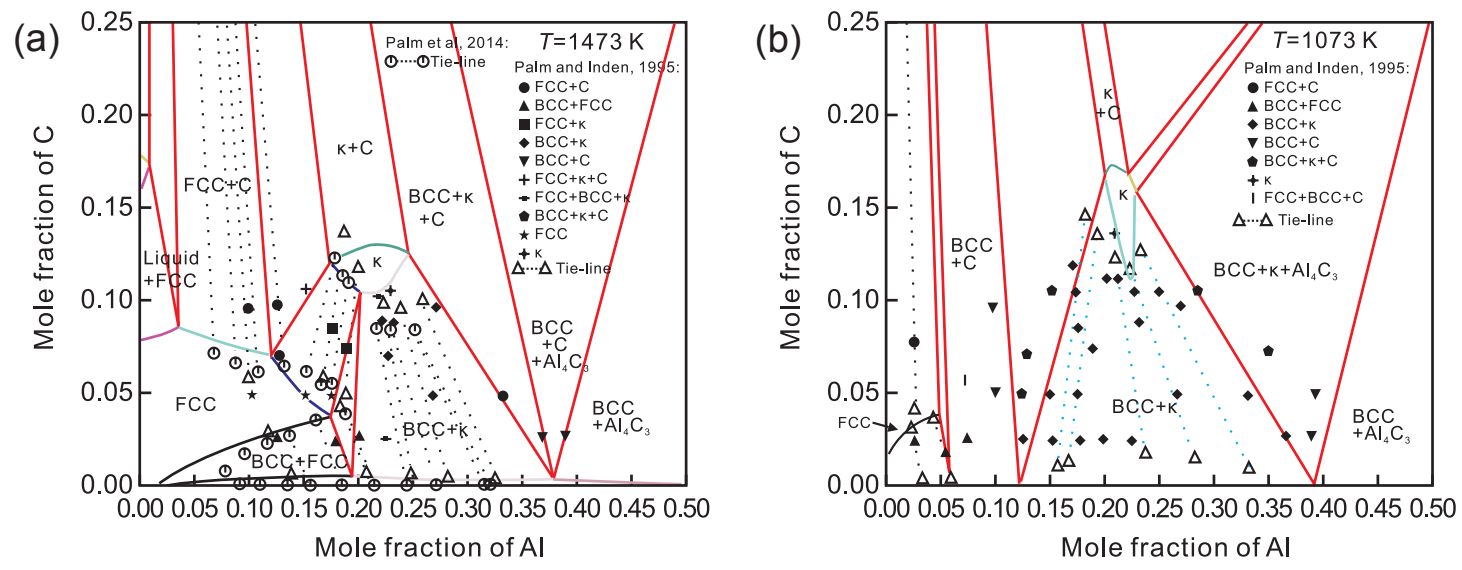

Fig. 1: Isothermal sections of the Al-C-Fe system at $1473 \mathrm{~K}(\mathrm{a}), 1073 \mathrm{~K}(\mathrm{~b})^{[12]}$. The dotted lines are experimental tie-lines from Refs. [13-14]

\section{Experimental procedure}

A cast iron was melted in a medium frequency induction furnace with a crucible capacity of $30 \mathrm{~kg}$. The furnace charge consisted of the pig iron with a maximum sulfur concentration of $0.02 \%$, ferro-silicon, ferro-manganese and the technically pure aluminium. The compacted graphite was obtained using the inmold method. The liquid cast iron at $1,480{ }^{\circ} \mathrm{C}$ was poured into a green sand mould. In its gating system, there was a spherical reaction chamber with a diameter of $\Phi 85 \mathrm{~mm}$. The magnesium master alloy Lamet ${ }^{\circledR} 5504$ containing about 5.5\% $\mathrm{Mg}$ was inside the chamber. Behind the reaction chamber, there was a mixing chamber in which the last portions of the master alloy were mixed with the liquid melt. The control chamber has a shape similar to the cylinder. A PtRh10-Pt thermocouple (Type S) was used for measuring the cast iron temperature. The signal of the thermocouple transfers from the voltage/frequency converter to a computer equipped with a program for recording thermal curve and its derivative. The diameter of the control chamber is approximately $38 \mathrm{~mm}$. Finally, the molten iron was poured, and a stepped bar with 3,6, 12 and $24 \mathrm{~mm}$ thicknesses was obtained.

From the central parts of the stepped casting, specimens for metallographic examinations were cut out. The sections were etched with nital and the microstructure was examined using a Nikon MA200 metallographic microscope. The phases fraction was examined using the NIS Elements BR (Basic Research) program. The cast iron's chemical composition was tested using an SPECTROMAXx arc spark OES metal analyzer, and the resutls are shown in Table 1.

Metallographic examinations were performed using a HITACHI S-3000N scanning electron microscope, on which the surface distributions of elements were also tested. The distributions were made by X-ray microanalysis with energy dispersion using a PIONEER detector cooperating with a scanning electron microscope and using the VANTAGE software. In order to determine the phases in cast iron, diffraction studies using the D-500 X-ray diffractometer from Siemens were carried out. The tests were conducted in the range of $2 \theta=180^{\circ}$ using a cobalt lamp with a wave-length of
Table 1: Chemical compositions of tested cast irons

\begin{tabular}{cccccc} 
No. & \multicolumn{5}{c}{ Chemical composition (wt.\%) } \\
& $\mathbf{C}$ & $\mathbf{S i}$ & $\mathrm{Mn}$ & $\mathrm{Al}$ & $\mathrm{Mg}$ \\
\hline 1 & 3.82 & 2.47 & 0.31 & - & 0.017 \\
2 & 3.75 & 2.46 & 0.35 & 0.19 & 0.017 \\
3 & 3.67 & 2.64 & 0.35 & 1.30 & 0.019 \\
4 & 3.60 & 2.61 & 0.34 & 2.39 & 0.018 \\
5 & 3.55 & 2.62 & 0.33 & 3.06 & 0.019 \\
6 & 3.50 & 2.66 & 0.33 & 5.12 & 0.018 \\
7 & 3.41 & 2.64 & 0.33 & 6.64 & 0.018 \\
8 & 3.33 & 2.73 & 0.35 & 8.20 & 0.019 \\
9 & 3.39 & 2.69 & 0.31 & 11.06 & 0.020
\end{tabular}

$1.79021 \AA$. The cast iron hardness was examined using a HPO2,400 hardness tester for the conditions: load: 1,840 N, ball diameter: $2.5 \mathrm{~mm}$. The microhardness tests were performed on an HV-1000B microhardness tester with a load of $0.09807 \mathrm{~N}$.

\section{Results and discussion}

The thermal curve and its derivative of non-alloyed CGI (Table 1, No.1) in the crystallization area and solid state transformation are shown in Fig. 2.

There are two curves in Fig. 2. The first one $[t=f(\tau)]$ shows the temperature changes vs. time, while the second one (derivative) shows the changes of cooling rate with time. On the derivative curve $d t / d \tau=f^{\prime}(\tau)$ (Fig. 2a), there are two thermal effects (heat release as a result of phase transformations) marked with characteristic points. The first thermal effect is derived from the primary austenite crystallization and it is described by Points $\mathrm{A}$ and $\mathrm{B}$. The second thermal effect comes from the eutectic mixture (austenite+compacted graphite) crystallization. It is described by Points D, E, F and H. Points D and F indicate 

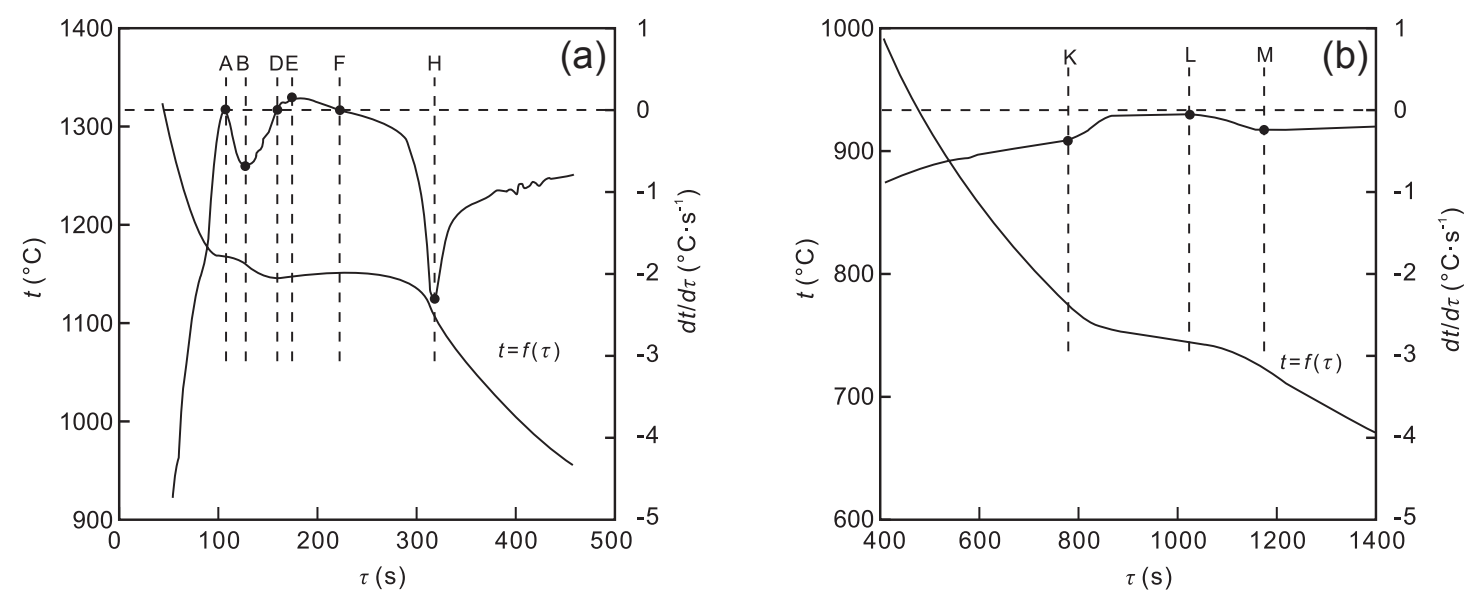

Fig. 2: Cooling curves of non-alloyed CGI in crystallization area (a) and solid state transformation (b)

the balance of heat released as a result of transformation and release into the environment. The highest temperature of eutectic transformation occurs at Point $\mathrm{F}, 1,168{ }^{\circ} \mathrm{C}$. The recalescence temperature $\left(t_{\mathrm{F}}-t_{\mathrm{D}}\right)$ is $4{ }^{\circ} \mathrm{C}$. The end of the eutectic transformation indicates the simultaneous end of the cast iron crystallization, which occurs at $1,126{ }^{\circ} \mathrm{C}$ (Point $\mathrm{H}$, Fig. 2a). Figure 2(b) shows that the austenite transformation $\gamma \rightarrow \alpha$ starts at $775^{\circ} \mathrm{C}$ (Point K). The greatest amount of heat is released at $745{ }^{\circ} \mathrm{C}$ (Point $\mathrm{L}$ ). The end of transformation in the solid state is marked as Point $\mathrm{M}\left(723^{\circ} \mathrm{C}\right)$.

Aluminium at a concentration of approx. $6.6 \mathrm{wt} . \%$ resulted in an increase in the temperature of phase transformations. Due to the graphitizing effect, a small addition of $\mathrm{Al}(\sim 0.2 \mathrm{wt} . \%$, No. 2 in Table 1) resulted in the lack of the thermal effect

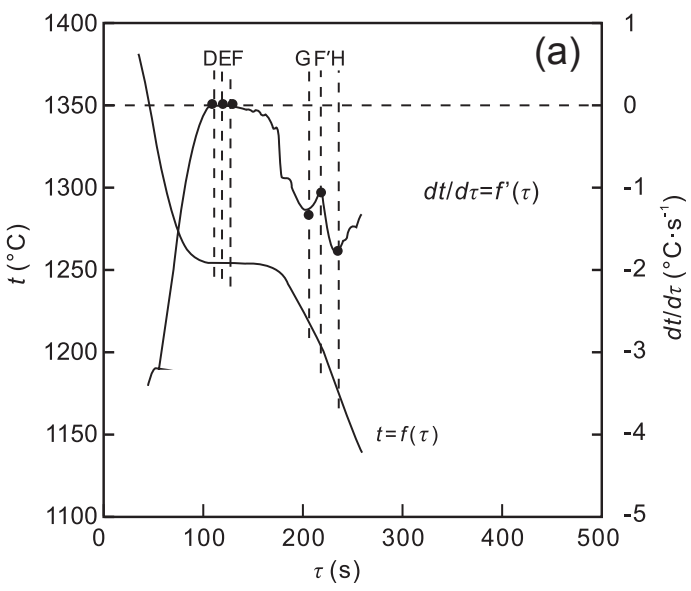

from the primary austenite crystallization (increase in eutectic carbon equivalent). Figure 3 shows the cooling curves of CGI containing $8.2 \mathrm{wt} . \% \mathrm{Al}$.

Figure 3 shows that the crystallization process starts with the transformation of liquid into $\gamma+$ graphite eutectic mixture (DEFG). This process finishes at $1,217^{\circ} \mathrm{C}$ (Point G). When the graphite eutectic crystallization is completed on the differential curve, an additional thermal effect appears, most likely from carbides crystallization. It is marked with Points $\mathrm{G}, \mathrm{F}^{\prime}$ and $\mathrm{H}$ and finishes at $1,177^{\circ} \mathrm{C}$. Figure 3 (b) shows the thermal effect coming from austenite transformation occurred at 1,162$1,022{ }^{\circ} \mathrm{C}$ (Points $\mathrm{K}, \mathrm{L}$ and $\mathrm{M}$ ). It starts just after the cast iron crystallization is finished. The effect of aluminium on the phase transformation temperature is shown in Fig. 4.

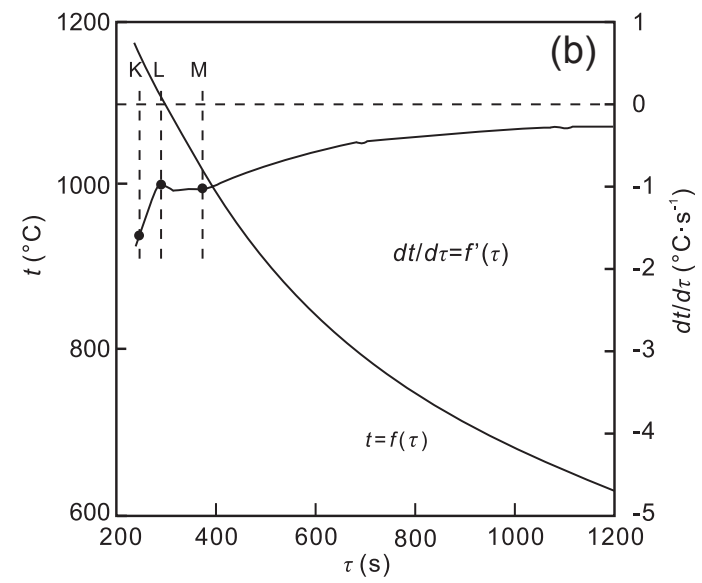

Fig. 3: Cooling curves of cast iron containing about $8.2 \mathrm{wt} . \% \mathrm{Al}$ in crystallization area (a) and austenite transformation area (b)

From Fig. 4, it can be found that aluminium obviously increases both the eutectic crystallization and the solid state transformation temperatures. For the cast iron with $11 \mathrm{wt} . \% \mathrm{Al}$, no thermal effect from solid state transformation was observed. It should be assumed that due to the high temperature, this thermal effect could occur together with that of carbide crystallization. In CGI, aluminium increases the highest eutectic transformation temperature $\left(t_{\mathrm{F}}\right)$ by $9.7^{\circ} \mathrm{C}$ per $1 \mathrm{wt} . \%$, and its finish temperature $\left(t_{\mathrm{H}}\right)$ by $11.5{ }^{\circ} \mathrm{C}$ per $1 w t . \%$. With far greater intensity, Al increases the austenite transformation temperature in the solid state. The austenite transformation start temperature $\left(t_{\mathrm{K}}\right)$ increases by 41.5 ${ }^{\circ} \mathrm{C}$ per 1 wt.\%, while its finish $\left(t_{\mathrm{M}}\right)$ by $32.6{ }^{\circ} \mathrm{C}$.

Figure 5 shows the microstructures of non-alloyed CGI in castings with a wall thickness of 3 and $24 \mathrm{~mm}$, respectively.

The matrix of the non-alloyed cast iron in thin-walled castings is pearlitic-ferritic (Fig. 5a), while in thick-walled castings is ferritic-pearlitic (Fig. 5b). The volume fraction of ferrite is $28 \%$ and $67 \%$, while the pearlite is $69 \%$ and $30 \%$, respectively. The remaining part of the microstructure is compacted graphite. 

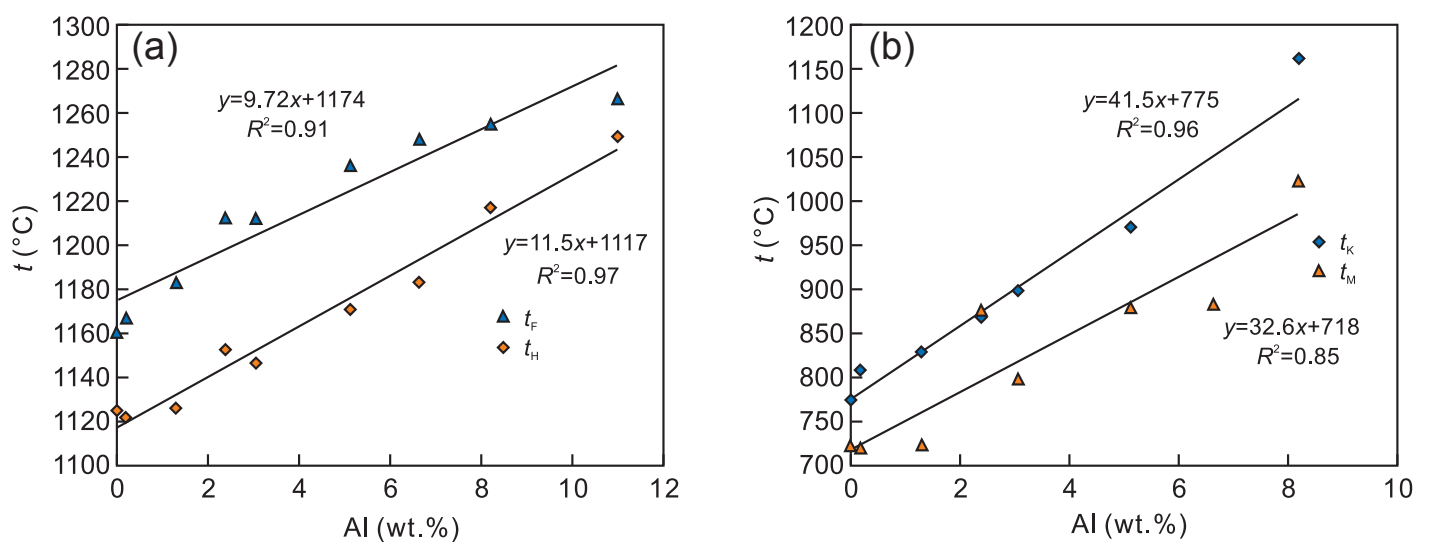

Fig. 4: Temperature of eutectic transformation (a) and eutectoid transformation (b) vs. aluminium concentration

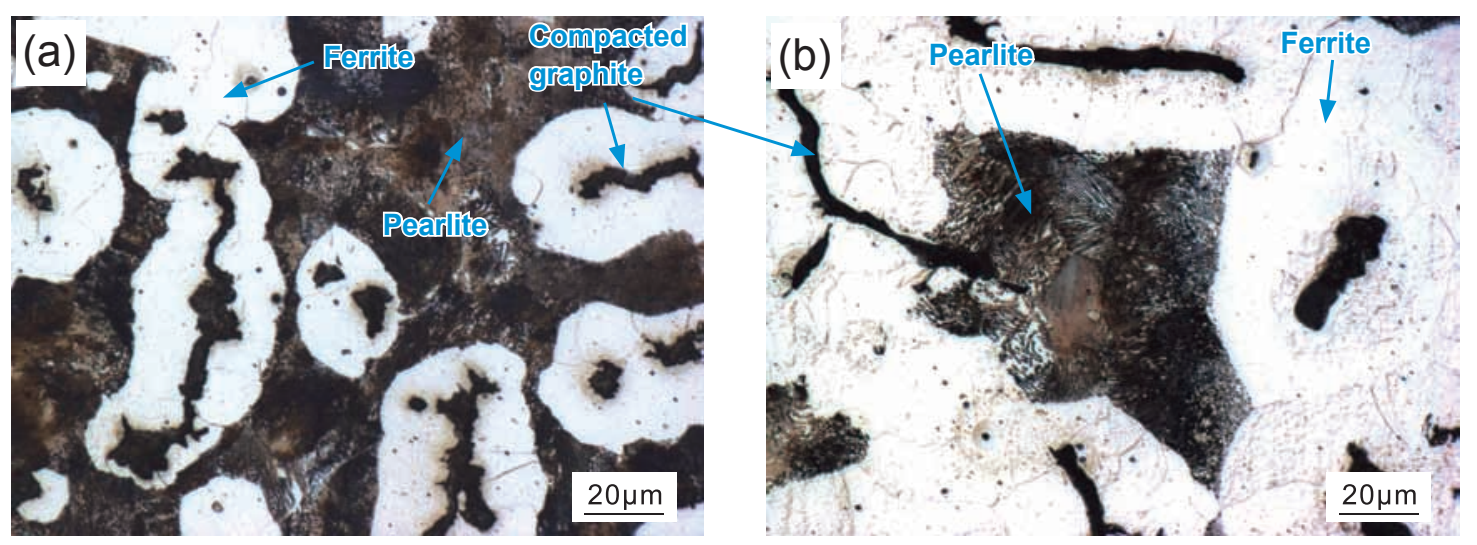

Fig. 5: Microstructures of non-alloyed CGI in castings with a wall thickness of $3 \mathrm{~mm}$ (a) and $24 \mathrm{~mm}$ (b)

Figure 6 shows the microstructures of CGI containing $2.4 \mathrm{wt} . \% \mathrm{Al}$ with different wall thicknesses.

The addition of $\mathrm{Al}$ clearly increases the volume fraction of ferrite in both thin-walled and thick-walled castings by $\sim 80 \%$ and $\sim 87 \%$, respectively. There was no change in the shape and size of the compacted graphite. Pearlite morphology has not yet changed.

The microstructures of CGI containing 3.1wt.\% $\mathrm{Al}$ are shown in Fig. 7, which show that the increase in $\mathrm{Al}$ concentration to $3.1 \mathrm{wt} . \%$ resulted in a slight increase in the volume fraction of pearlite (up to $\sim 22 \%$ in thin-walled and $12 \%$ in thick-walled castings). What is more, the spheroidization of the cementite in pearlite was observed. The reason for this is most likely the high temperature of the austenite transformation (in the range of 799$896^{\circ} \mathrm{C}$ ). The average size of the graphite particles was slightly reduced.

The microstructures of CGI containing $8.2 \mathrm{wt} . \% \mathrm{Al}$ are shown in Fig. 8. Due to the high concentration of $\mathrm{Al}$, the eutectoid is a mixture of ferrite and Kappa phase, which is referred to as $\mathrm{Fe}_{3} \mathrm{AlC}_{n}$ or $\gamma^{\prime}{ }^{[1]}$. In the microstructure of cast iron containing $8.2 \% \mathrm{Al}$, primary $\kappa$ phase precipitations are also visible. Its volume fraction decreases as the thickness of the casting wall decreases. Its shape indicates that the carbides are crystallized
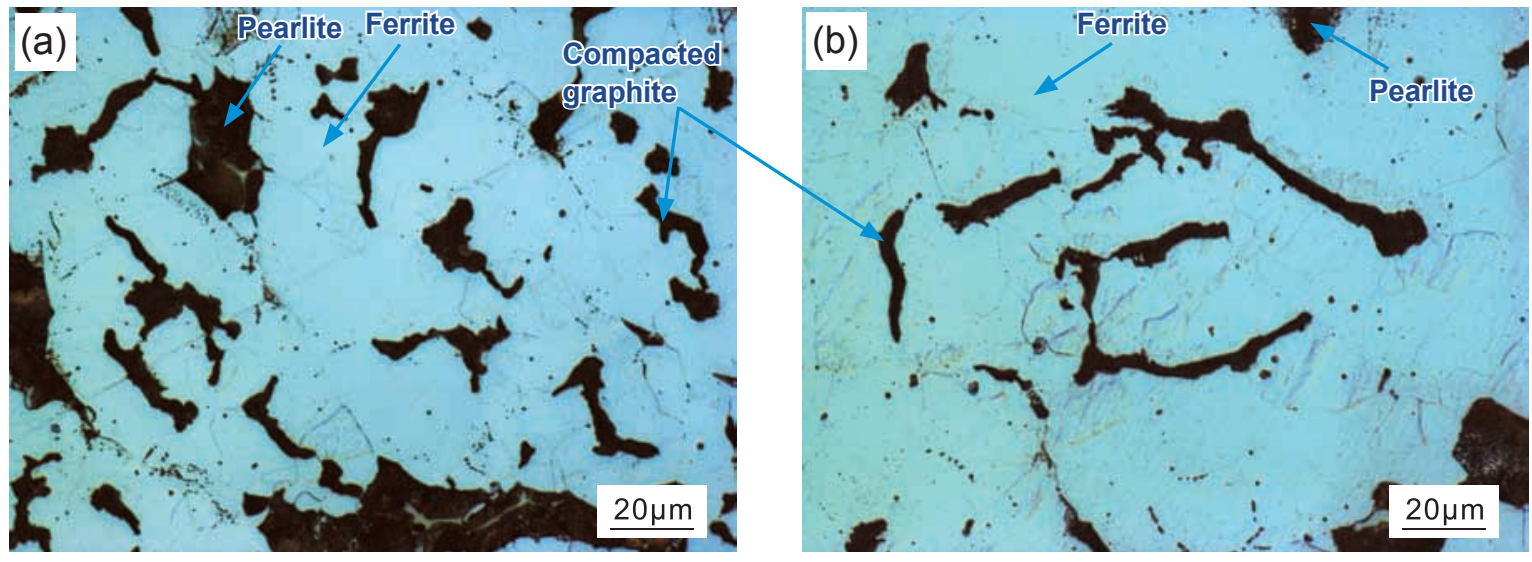

Fig. 6: Microstructures of CGI containing 2.4wt.\% Al in castings with a wall thickness of $3 \mathrm{~mm}$ (a) and $24 \mathrm{~mm}$ (b) 


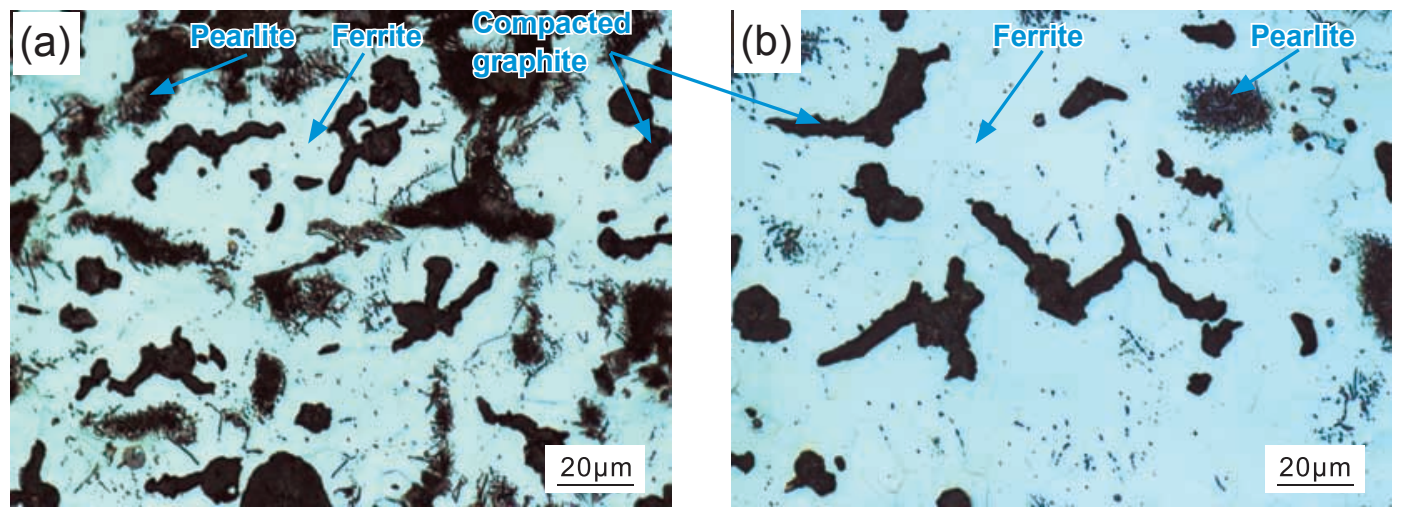

Fig. 7: Microstructures of CGI containing 3.1wt.\% Al in castings with a wall thickness of $3 \mathrm{~mm}$ (a) and $24 \mathrm{~mm}$ (b)
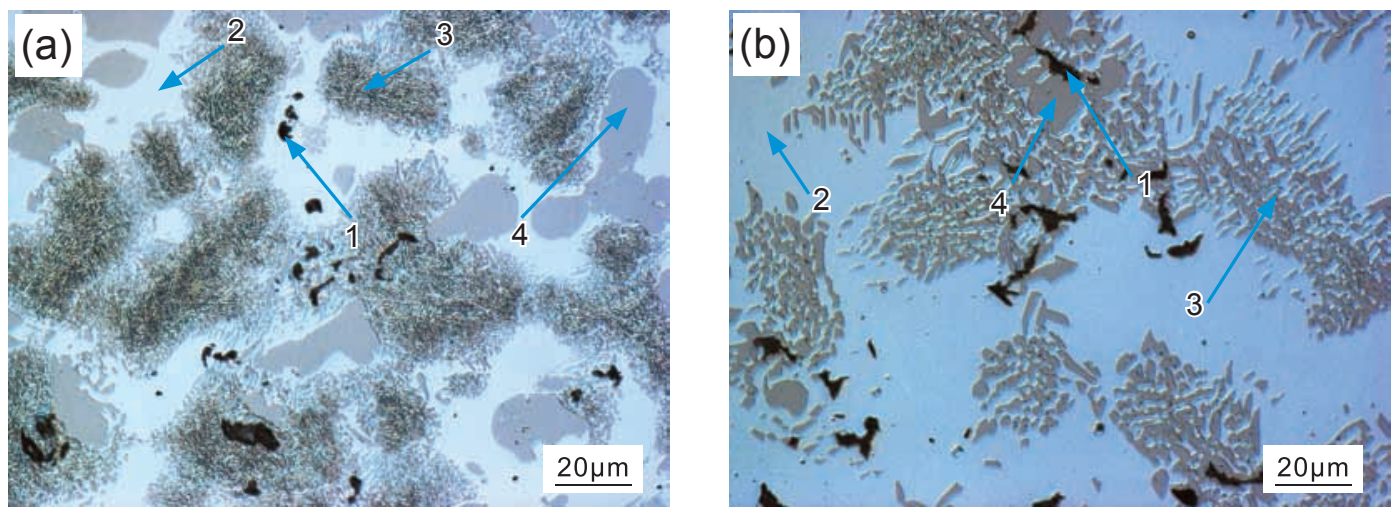

Fig. 8: Microstructures of CGI containing $8.2 \mathrm{wt} . \% \mathrm{Al}$ in castings with the wall thickness of $3 \mathrm{~mm}(\mathrm{a})$ and $24 \mathrm{~mm}$ (b): 1-compacted graphite, 2-ferrite, 3-eutectoid mixture (Kappa phase+ferrite), 4-carbides (K phase)

directly from the liquid. This is confirmed by the thermal effect occurring after the crystallization of (austenite+compacted graphite) eutectic mixture (Fig. 3a). Compared to cast iron containing $6.7 \mathrm{wt} . \% \mathrm{Al}$, the fraction of eutectoid in both thinand thick-walled castings decreases slightly. A further increases in Al up to $\sim 11$ wt.\% results in the changes shown in Fig. 9.

In the microstructure, there are few graphite precipitations, which have a spherical shape, therefore it is not CGI. Primary carbides ( $\kappa$ phase) constitute most of the cast iron components (darker areas). In addition, the eutectoid mixture ( $\kappa$ phase + ferrite) is found in an amount of $10 \%$ and $22 \%$ (3 and $25 \mathrm{~mm}$, respectively).

It can be found from Figs. 5-9 that the 2.4wt.\% aluminium shows a graphitizing effect, while in higher concentrations aluminium is a carbide-forming element. At a concentration higher than $8.2 \mathrm{wt} . \%$, the eutectic crystallization occurs partly according to the metastable system. On the basis of the phases fraction, nomograms showing the effect of aluminium on the cast iron microstructure in castings with a wall thickness of 3 and $25 \mathrm{~mm}$ (Fig. 10) are developed.

Figure 10 shows that up to $2.5 \mathrm{wt} . \% \mathrm{Al}$ significantly reduces the pearlite fraction with a slight increase in the graphite fraction. When Al concentration is greater than $3 \mathrm{wt} . \%$, cementite is gradually replaced by the precipitation of phase $\kappa$ [no distinct boundary in pearlite and $(\kappa$ phase $+\alpha)$ eutectoid mixture]. The ferrite volume fraction in thick-walled castings is greater,
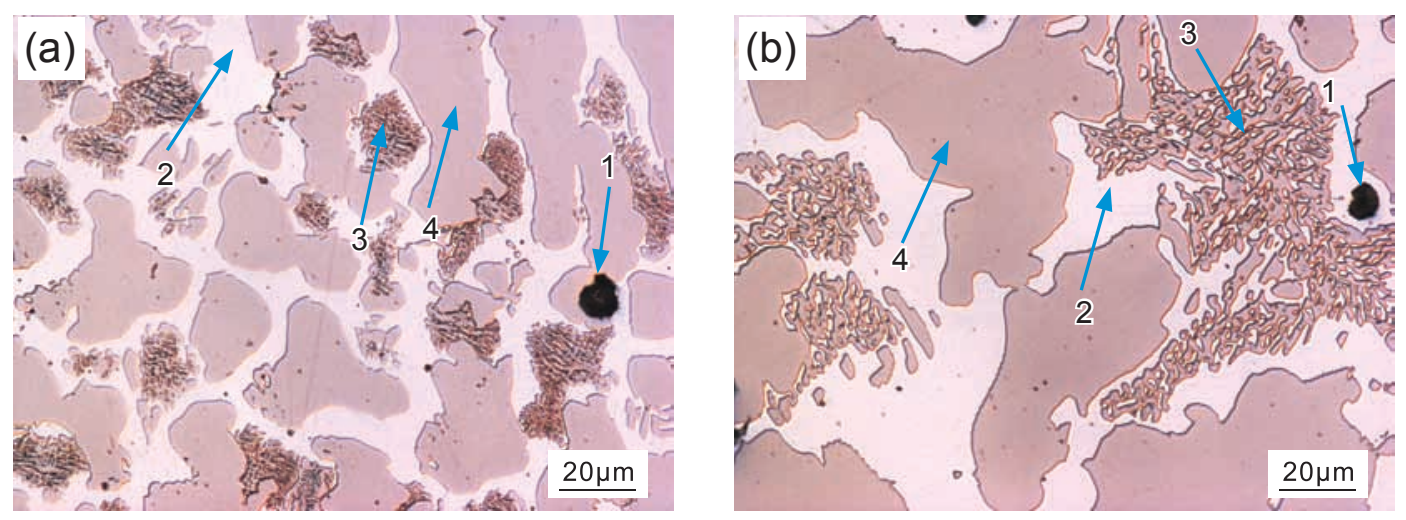

Fig. 9: Microstructure of cast iron containing $11 \mathrm{wt} . \% \mathrm{Al}$ in castings with wall thickness of $3 \mathrm{~mm}$ (a) and $24 \mathrm{~mm}$ (b): 1-graphite, 2-ferrite, 3-eutectoid mixture ( $\kappa$ phase +ferrite), 4-ү' carbides ( $\kappa$ phase) 

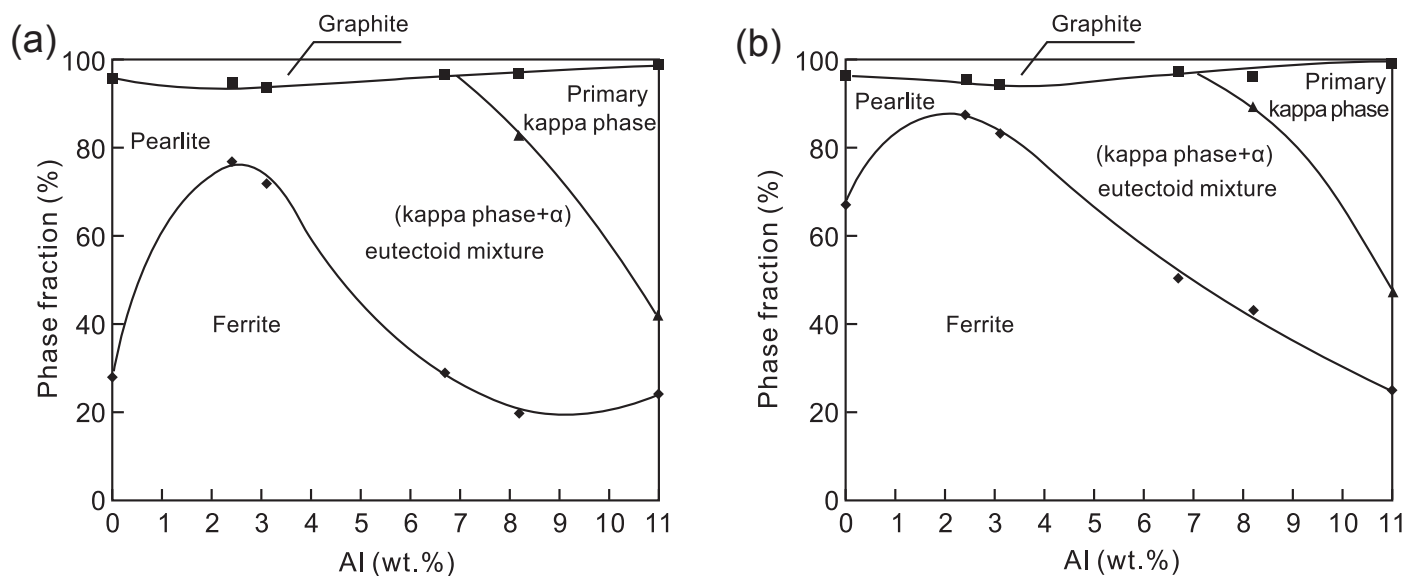

Fig. 10: Phases volume fraction in aluminium cast iron castings with wall thickness: $3 \mathrm{~mm}$ (a) and $25 \mathrm{~mm}$ (b)

especially at $\mathrm{Al}$ concentrations higher than 3wt.\%. The primary $\kappa$ phase fraction is greater in thin-walled castings (Fig. 10a).

Figure 11 shows the chemical composition of phases in cast iron containing $11 \mathrm{wt} . \% \mathrm{Al}$. It shows that the light gray phase is ferrite with $\mathrm{Al}$ and $\mathrm{Si}$, while the dark phase is $\kappa$ phase $\left(\gamma^{\prime}\right.$ carbide) with high concentration of Al.
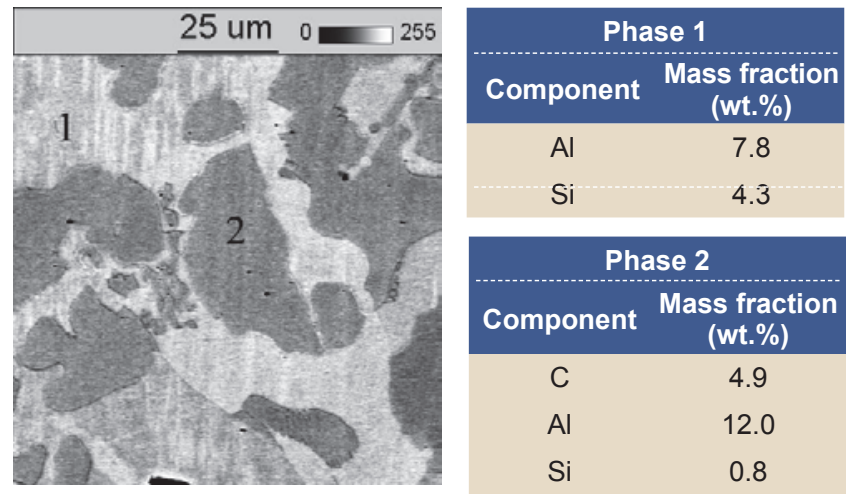

Fig. 11: Chemical composition of phases in cast iron containing 11 wt. $\% \mathrm{Al}$

To identify the above mentioned phases, the diffraction pattern for cast iron containing $11 \mathrm{wt} . \% \mathrm{Al}$ is shown in Fig. 12.

Figure 12 shows that there are two phases in the tested area: $\mathrm{Al}_{0.7} \mathrm{Fe}_{3} \mathrm{Si}_{0.3}$ and $\mathrm{AlFe}_{3} \mathrm{C}_{0.5}$. Due to the fact that the eutectoid volume fraction is about $23 \%$, it is very likely that the chemical

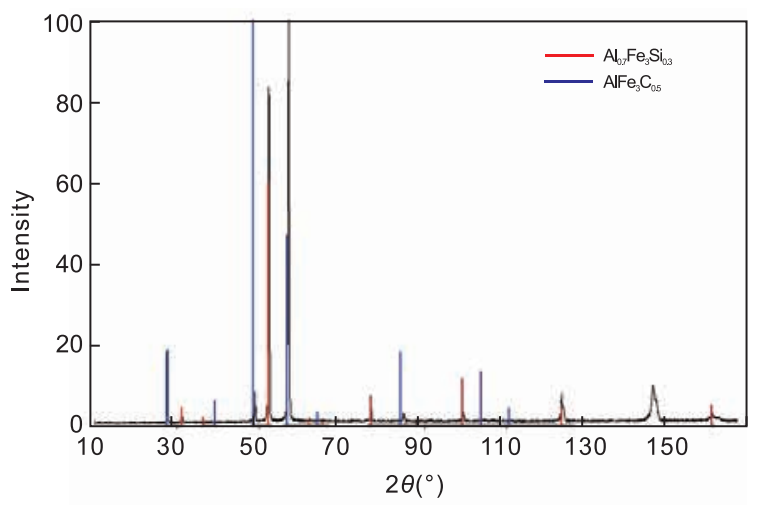

Fig. 12: Diffraction pattern for cast iron containing 11 wt. \% Al composition of the carbides in the eutectoid is the same as the primary carbides (Phase 2 in Fig. 11a).

Figure 13 shows the effect of aluminium on the CGI hardness. Assuming that the increase in hardness is proportional to the concentration, $\mathrm{Al}$ increases the hardness of CGI by $22 \mathrm{HB}$ per 1wt.\%. It should be noted, however, that with $\mathrm{Al}$ concentration higher than $6 \mathrm{wt} . \%$, the increase in hardness is slight.

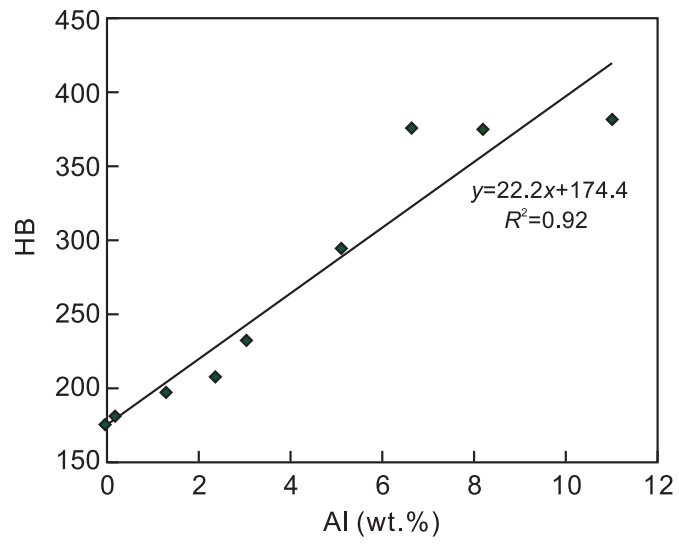

Fig. 13: Cast iron hardness vs. aluminium concentration

Figure 14 shows the effect of aluminium on the ferrite microhardness in CGI. The data presented in Fig. 14 shows that $\mathrm{Al}$ significantly increases the ferrite microhardness by 21 $\mu \mathrm{HV}$ per $1 \mathrm{wt} . \%$.

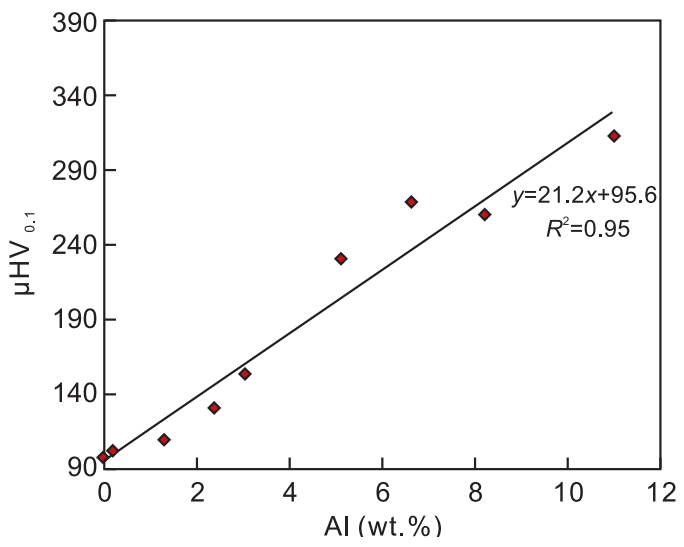

Fig. 14: Ferrite microhardness vs. aluminium concentration 


\section{Conclusions}

From the data discussed above, the following conclusions can be drawn:

(1) Aluminium increases the highest eutectic transformation temperature in CGI by about $11.5^{\circ} \mathrm{C}$, and the finish temperature of the eutectic transformation by about $11^{\circ} \mathrm{C}$ per $1 \mathrm{wt} . \%$.

(2) Aluminium strongly increases the start temperature of the austenite transformation (i.e. transformation in the solid state) in CGI by about $42{ }^{\circ} \mathrm{C}$, and the finish temperature by about $33{ }^{\circ} \mathrm{C}$ per 1 wt. $\%$.

(3) Aluminium, with a concentration of up to $2.4 \mathrm{wt} . \%$, exhibits graphitizing properties, above this concentration it is a carbide-forming element.

(4) At a concentration higher than 3.1wt.\%, Al causes carbide spheroidization in the eutectoid mixture, and cementite precipitations are replaced by $\kappa$ phase,

(5) Increase in aluminium concentration by $1 \mathrm{wt} . \%$ results in an increase in ferrite microhardness by about $21 \mu \mathrm{HV}$, and CGI hardness by about $22 \mathrm{HB}$.

(6) With an aluminium content higher than $8 \%$, the $\mathrm{AlFe}_{3} \mathrm{C}_{0.5}$ phase crystallizes from the liquid.

\section{References}

[1] Lim C-H, Goo B-C. Development of compacted vermicular graphite cast iron for railway brake discs. Metals and Materials International, 2011, 17 (2): 199-205.

[2] Zhou G, Liu W H. Production technique of vermicular graphite iron cylinder head of vehicle diesel engine. China Foundry, 2008, 5 (3): 153-161.

[3] Laneri K, Bruna P, Crespo D. Microstructural characterization and kinetics modelling of vermicular cast irons. Materials Science and Technology, 2008, 24 (10): 1214-1221.

[4] Guzik E, Kleingartner T. A study on the structure and mechanical properties of vermicular cast iron with pearliticferritic matrix. Archives of Foundry Engineering, 2009, 9 (3): $55-60$.

[5] Górny M, Kawalec M. Effects of titanium addition on microstructure and mechanical properties of thin-walled compacted graphite iron castings. Journal of Materials Engineering and Performance, 2013, 22 (5): 1519-1524.

[6] Tooptong S, Park K H, Lee S W, et al. A preliminary machinability study of flake and compacted graphite irons with multilayer coated and uncoated carbide inserts. Procedia Manufacturing, 2016, 5: 644-657.

[7] Bacior M, Sobczak N, Homa M, et al. High-temperature interaction of molten vermicular graphite cast iron with $\mathrm{Al}_{2} \mathrm{O}_{3}$ substrate. Transactions of the Foundry Research Institute, 2017, 57 (4): 375-384.

[8] Fragassa C, Pavlović A. Compacted and spheroidal graphite irons: experimental evaluation of Poisson's ratio. FME Transactions, 2016, 44 (4): 327-332.

[9] Lopez-Covaleda E, Ghodrat S, Kestens L, et al. Proposal of characterization procedure of metal-graphite interface strength in compacted graphite iron. Materials, 2018, 11 (7): 1159.
[10] Gregorutti R W, Grau J E. Mechanical properties of compacted graphite cast iron with different microstructures. International Journal of Cast Metals Research, 2014, 27 (5): 275-281.

[11] Soiński M S. Low-aluminium cast iron. Częstochowa, 2012, 26. (In Polish)

[12] Zheng W, He S, Selleby M, et al. Thermodynamic assessment of the Al-C-Fe system. Calphad, 2017, 58: 34-49.

[13] Palm M, Inden G. Experimental determination of phase equilibria in the Fe-Al-C system. Intermetallics, 1995, 3 (6): 443-454.

[14] Phan A T, Paek M-K, Kang Y-B. Phase equilibria and thermodynamics of the Fe-Al-C system: critical evaluation, experiment and thermodynamic optimization. Acta Materialia, 2014, 79: 1-15.

[15] Safronov N N, Kharisov L R, Safronov G N. Aluminium-alloyed cast iron with compact graphite inclusions from fine production wastes. Processes of Manufacture of Ferrous and Nonferrous Metals, 2017, 17: 1207-1209.

[16] Elbel T, Hampl J. Influence of Al and Ti on microstructure and quality of compacted graphite iron castings. Metalurgija, 2009, 48 (4): 243-247.

[17] Soiński M S, Jakubus A, Stradomski G. The influence of aluminium on the spheroidization of cast iron assessed on the basis of wedge test. Archives of Foundry Engineering, 2013, 13 (1): 163-168.

[18] Elbel T, Hampl J, Vladík R, et al. Influence of aluminium on the formation of pinholes in cast irons. Archives of Foundry Engineering, 2008, 8 (2): 27-32.

[19] Kashani S M, Mostafavi B S M A. As-cast acicular ductile aluminium cast iron. Journal of Iron and Steel Research, International, 2009, 16 (6): 23-28.

[20] Boutorabi S M. Fracture characteristics of austempered spheroidal graphite aluminium cast irons. In: Proc. International Symposium on Processing and Fabrication of Advanced Materials VI, Singapore, 1997.

[21] Zhi X, Han Y, Lui J. Effect of aluminium on the primary carbides of a hypereutectic high chromium cast iron. Material Science \& Engineering Technology, 2015, 46 (1): 33-39.

[22] Soiński M S, Jakubus A, Kordas P, et al. The effect of aluminium on graphitization of cast iron treated with cerium mixture. Archives of Foundry Engineering, 2014, 14 (2): 95-100.

[23] Kutalia E, Khidasheli N, Tsurtsumia O, et al. The contact fatigue and the wear of DADI class aluminium cast iron. Procedia Engineering, 2010, 2 (1): 1219-1224.

[24] Takamori S, Osawa Y, Halada K. Aluminium-alloyed cast iron as a versatile alloy. Materials Transactions, 2002, 43 (3): 311-314.

[25] Soiński M S, Warchala T, Zyska A. The effect of aluminium on the maximum temperature of eutectic transformation and the volume of the cast iron eutectic recalescence. Archives of Foundry, 2003, 3 (10):175-180. (In Polish)

[26] Soiński M S, Kukla $Ł$. The research on the production of low aluminium-chromium cast iron with compacted graphite. Archives of Foundry, 2006, 6 (18): 165-170. (In Polish)

[27] Malakizadi A, Sadik I, Nyborg L. Wear mechanism of CBN inserts during machining of bi-metal aluminium-grey cast iron engine block. Procedia CIRP, 2013, 8: 188-193.

[28] Safronov N N, Kharisov L R, Safronov G N. Aluminium-alloyed cast iron with compact graphite inclusions from fine production wastes. Processes of Manufacture of Ferrous and Nonferrous Metals, 2017, 17: 1207-1209. 